\title{
Pathway, Strategy and Mechanism of Training Double-Qualified Teachers
}

\author{
Ye Tao \\ Department of Computer \\ Wuhan Polytechnic \\ Wuhan 430074, China \\ 867327860@qq.com
}

\begin{abstract}
There are some problems in the construction of double-qualified teachers because of its definition. The double teacher type should have the quality. In 2016, the Ministry of Education issued a document to strengthen the construction of double-qualified teachers. This paper expounds the ways, strategies and mechanisms of the construction of double-qualified teachers.
\end{abstract}

Keywords-double teacher; problem; cultivation approach; mechanism; strategy

\section{The Present Situation of Double-Qualified Type TEACHERS}

Since the 1990s, China's economic system reform has been deepening, and the new economic situation has put forward new requirements for the development of vocational education. "We will improve vocational education and training systems and deepen integration between industry and education and cooperation between schools and enterprises," XI Jin-ping stressed in his report to the 19th CPC National Congress. This means that vocational colleges no longer exist as educational institutions that are independent of the market, and vocational education and industry need to form a two-way communication linkage mechanism, accelerate the close connection between industry and teaching, and realize the effective integration of school-enterprise elements. In 2016, the Ministry of Education issued The Opinions on the Implementation of the Plan for Improving the Quality of Teachers in Vocational Colleges (2017-2020), which proposed to further strengthen the construction of "double-qualified" teachers in vocational colleges and promote the development of vocational education to achieve new breakthroughs. And "double teacher and double ability" is a further refinement of the "double teacher type" to "double teacher quality" proposed by the relevant documents of the education policy for the construction of higher vocational teachers. Education is the link of knowledge transmission. To develop vocational education well in the new century, schools and enterprises need to cooperate to build a team of sufficient "double-qualified and double-capable" teachers with good quality. Up to now, the research on "double-qualified teachers" is relatively comprehensive, but the academic circle has not yet made a clear and unified definition of the concept of "doublequalified teachers". "Double teachers and double ability" teachers are derived from the connotation of "double teachers", and their extension are larger than "double teachers". The definition of "double-qualified and double-capable" teacher mainly includes "double-qualification theory", "double-ability theory" and "double-quality theory". "Double qualification" refers to the teacher who has passed the national teacher qualification examination and obtained the professional title, and also acquired the professional qualification certificate and professional technical title in the actual field; "Double ability" means that teachers not only need to have daily teaching ability but also the practical application ability; "Double quality" means professional dedication and social responsibility. The above viewpoints describe the characteristics of "dual-teacher and dual-energy" teachers from different perspectives, but they still fail to give a complete and systematic explanation. The generalization or alienation of connotation makes it difficult to locate the professional identity of "double-qualified and double-capable" teachers, and also causes some problems in the construction of "double-qualified and double-capable" teachers[1].

II. The ABility Elements of TeAcher Professional DEVELOPMENT OF "DOUble PROFESSIONAL TYPE" IN HigheR VOCATIONAL COLLEGES

As a type of institutions of higher learning, higher vocational colleges also have the functions of human cultivation, scientific research, social service and cultural inheritance and innovation. Therefore, it is necessary to reflect the functions of higher vocational colleges when discussing the factors of ability and quality for the professional development of double-qualified teachers in higher vocational colleges. Based on the comprehensive consideration of the educational characteristics of higher vocational education, the professional quality of "double-qualified" teachers and the functions of higher vocational colleges, the ability elements of constructing the professional development of "double-qualified" teachers in higher vocational colleges include the following aspects[2][3]:

\section{A. Code of ethics requirements}

Professional ethics need to be in line with the requirements of the Ministry of Education "code of professional ethics for college teachers" and the cultivation of good teacher ethics should be put in the first place in the ability of double teachers, running through the whole career development of higher vocational teachers. In the process of cultivating backbone teachers, professional leaders, teaching masters and building 
excellent teacher teams, the construction of teacher ethics project should be highly emphasized. The content of teaching quality, such as strict teaching and skilled skills, focuses on the requirements of classroom teaching.

\section{B. Classroom teaching ability}

Teaching ability means that teachers are required to design, organize and implement teaching activities in order to achieve teaching objectives. Its main components include cognitive ability, language expression ability, teaching design ability, information technology application, teaching organization ability, teaching evaluation ability and teacher-student communication ability. Different types of colleges and universities will lead to different emphases of the elements of teachers' teaching ability, and the particularity of the positioning of higher vocational education makes its requirements on teachers' teaching ability particular [2]. For example, the ability to use teaching resources in combination with knowledge or skills, the ability to embody the characteristics of vocational education by teaching methods such as project teaching, task-driven teachingand integration of knowledge and action, the ability to pay attention to the cultivation of students' professional quality and to use professional knowledge and skills, the ability to practice operation skill demonstration specification, the ability to flexibly use various teaching evaluation methods and so on are combined with the practice of students in theory learning and practical training.

\section{Professional practical ability}

Professional practical ability is the most important ability that distinguishes double-qualified teachers from other types of college teachers. The teaching with the cultivation of applied talents of higher vocational education and curriculum content reflect the working process, practice the simulation professional situation and serve the local economy development, so the "double type" teachers should have relevant professional or trade required for professional practice ability and be able to manage real integration teaching, hence improving teaching methods combined with professional practice. Professional practical ability is shown in the following ways: obtaining professional and industrial qualification certificates, or having the qualification of professional skill examiners, or organizing targeted assessment of school-based technical skills in higher vocational colleges. According to the latest Ministry of Education "vocational school teacher enterprise practice regulations" requirements, professional teachers' accumulative practical time of no less than 6 months in every 5 years can guide professional practical training teaching, which can help preside over or participate in the construction of campus practical teaching facilities. Social service ability is an extension of teachers' professional practice ability, which can be added to the requirements of middle-aged and young backbone teachers, professional leaders and famous teachers, that is, they can carry out training, production and technical services according to the needs of industrial enterprises, and boast the ability of research and development and promotion of substantive application technology in the technical field of industrial enterprises.

\section{The Way to Cultivate the Double Quality oF TEACHERS}

Higher vocational education is inseparable from the support of teachers' practical knowledge. Only when teachers in higher vocational colleges achieve the organic integration and twoway transformation of theoretical and practical knowledge can they truly possess the quality of double teachers and be qualified for their teaching work. It is an effective way to train and improve the quality of teachers in higher vocational colleges to participate in practical activities. The practice place of teachers in higher vocational colleges can not only be limited to enterprises, but must closely follow the discipline and professional practice. The author thinks that the professional practice of higher vocational teachers in recent years mainly has the following forms.

\section{A. Part-time job training}

A part-time job is one that does not deviate from one's duty but concurrently holds another post. The temporary post refers to the position assigned by an organization to another post while retaining the original position. It is an important way to effectively improve teachers' professional practical ability and cultivate the quality of double-qualified teachers by sending teachers to enterprises (banks), scientific research institutes and similar vocational colleges to hold concurrent or temporary posts in production, service, management and scientific research related to the major. Teachers want to choose the production spot post that is close to their majors as part-time or temporary post; they do not want to choose part-time or temporary post that is divorced from actual second or third line post.

\section{B. Application technology research and development}

For the applied technology research and development of higher vocational teachers as a teacher's professional practice in the form of research and development work, it is to point in higher vocational colleges and enterprises and industry cooperation to send teachers to preside over or participate in production, service and management, the application of technology research, advanced technology, scientific research, technical innovation and new products, new technology research and development, etc. The author thinks that higher vocational colleges should be aware of their own advantages, find their own position, keep in mind the needs of the region and the industry, and solve practical problems. The foundation of school-enterprise cooperation is to find the interest combination point of school-enterprise combination. In the course of cooperation, the hardware and software resources and advantages of the two sides can be exchanged and complemented to achieve mutual benefit. The development of school-enterprise cooperation is not only the need for the development of higher vocational colleges, but also an effective way to cultivate the quality of teachers.

\section{To carry out various forms of social practice}

The main function of social practice is to promote the cognitive development, skill formation and emotional experience of participants. Therefore, the social practice activities aim at improving the practical ability of dual-teacher 
teachers in higher vocational colleges that is also an important form of accumulating professional practical experience. The form of social practice can be flexible as long as the content can be closely related to the professional and curriculum activities, including understanding the application of new technology and new process; carrying out social investigation activities, tracking the technological trends, and collecting teaching cases; carrying out science and technology to the countryside under the enterprise activities in a variety of forms to serve the community; giving full play to the technical advantages and undertaking some projects such as equipment installation, commissioning, maintenance and market research, product sales and so on. Through these forms of diversified social practice activities, good practice results can be achieved. In practice, teachers can cultivate their professional emotions, exercise and improve their hands-on ability, and accumulated rich practical experience. Teachers should also take the initiative to find ways to foster the quality and ability of double teachers. For example, I actively participated in various technical and skill training and vocational qualification examinations at all levels, and actively took part in the construction of school practice and training bases and the teaching of practice and training. In a word, double quality teacher cultivation of higher vocational colleges should make full use of various resources, fully explore various channels face-to-face and adjust measures to local conditions Since the implementation of teacher training plan, effective organization is carried out in professional practice activities; ultimate goal is formed in mutual rotation; interactive teaching and practice, complement knowledge and skills of teachers' professional development mechanism are also taken shape.

\section{School-enterprise cooperation and exchange}

We should establish a school-enterprise interactive communication platform based on the school's personnel department (or school-enterprise cooperation office) and the enterprise's human resources department. Through regular meetings between the two sides according to the demand and technical information of colleges and enterprises , a variety of forms such as Open Day between colleges in talent exchange, students' employment, staff training, regular communication, technology application and development are formed to explore technology development and personnel training and other related matters, and to promote the exchanges of teachers and enterprise technical personnel.

The personnel department of the university and the enterprise shall organize more than two meetings between the person in charge of the personnel department of the university and the enterprise every year to understand the development situation of the enterprise, the demand for human resources and for technical and skill improvement of the on-duty employees, implement the exchange plan of the two teachers, analyze and communicate the development situation of the work, and provide personnel training services for the development of the enterprise in time.

According to their own intrinsic demand, the school and the enterprise formulate the school enterprise two-way service policy and the mechanism. For example, in the form of projects, enterprises carry out the research and development of new products, the application of new technologies and the technical transformation of equipment with the help of the school's advantageous projects such as teachers, sites and technical services[4]. Schools may, according to their own needs, send professional teachers to participate in "industry-universityresearch-practice" or " enterprise practice", so as to improve teachers' technical application and social service ability.

\section{DOUBLE TEACHER TRAINING STRATEGY}

Higher vocational college "double type" teachers' professional development runs through the whole career development of teachers. Teachers need to continue to their own practice, self-reflection and self-improvement, at the same time they need to be in the education administrative departments at all levels. Universities and colleges, higher vocational colleges, vocational education group and industry enterprise set up different subjects and levels of synergy mechanism[5].

\section{A. To improve the teacher recognition system for double teachers}

It is a necessary precondition for promoting the standardized development of double-qualified teachers in vocational colleges and universities to clarify their evaluation criteria. First of all, the core competence of teachers should be highlighted, and then a dual-teacher qualification certification system based on competence should be established. The author thinks that colleges and universities can further refine the standards according to the standards of the evaluation program of the Ministry of Education to reflect the connotation characteristics of double-qualified teachers. In the recognition of double teachers, we should lay more emphasis on other ways besides double certificates and double professional titles.

\section{B. Accelerate the construction of double division training base}

Most vocational colleges have created a professional atmosphere on and off the campus and built the experimental practice base, teaching such as hospital, practice base set production, scientific research, industry research and development for the integration of productive practice base, large scale, hard and soft facilities, advanced equipment have brought the school good teaching, social and economic benefits. The practice shows that in order to accelerate the development of the construction of double-qualified teachers, it is necessary to build a training base for double-qualified teachers and make it the cradle for their growth.

\section{Pre-service probation mechanism}

The cooperation and joint running of higher vocational colleges and enterprises is an important trend in the development of modern higher education. Higher vocational education is to cultivate technical and skilled talents, which is difficult to achieve merely by school education, however, it also relies on industries and enterprises. Therefore, it is particularly important for double-qualified teachers in vocational colleges to carry out professional practice in enterprises before teaching. We should constantly improve the 
level of theory of double teachers, education level, the ability of production, management, construction, servicing the first line or school training base and the base of production, study and research work for a period of time, practicing, and solving some practical problems, thus improving the ability at the beginning and operation level to achieve the goal of reserve practical experience.

\section{To establish a long-term mechanism of industry-university- research cooperation with the industry association}

One of the characteristics of modern enterprises is that various technologies and skills are updated quickly and in a short period. This makes us realize that the cultivation of double-qualified teachers must be a cyclic process, putting forward higher requirements on the cultivation mechanism of double-qualified teachers in higher vocational colleges. If it is not done well, the early training input and the harvested training results will soon become invalid, which requires higher vocational colleges to establish an effective circular training mechanism. It is an important way to retrain "double teachers" by taking turns to practice in enterprises. When developing the re-practice training mechanism, higher vocational colleges should make it clear in the practical requirements that teachers should understand the production and organization mode of enterprises, advanced technology, technology and process, and the development trend of industry in detail. Teachers should be familiar with the specific contents of job responsibilities, operation specifications, employment standards and management systems related to the enterprise (bank) industry; study and discuss the application and technical development direction of new knowledge, new skills, new process and new methods related to their majors in production practice; be in line with the actual employment standards and requirements of enterprises (banks), research on new teaching methods and teaching models to improve the practical teaching links in schools and improve the quality of skilled personnel training. How to grasp the specific training plan when selecting and dispatching teachers is the key first step that directly affects whether the training effect can be received. The specific practical work plan should be applied by the teaching and research department as the unit, the individual, the director of the teaching and research department for examination and approval, the department for examination and approval, the college for examination and approval, so as to keep the practice content and training objectives on track. Another key point that higher vocational colleges should pay attention to is the establishment of training effect assessment mechanism. The specific implementation is to elaborate and quantify the training requirements mentioned above and develop an assessment scheme to ensure the effect of practical training.

\section{CONCLUSION}

In terms of the construction of double-qualified teachers in higher vocational education, higher vocational colleges should actively explore, dare to innovate, develop a set of highly operable and effective ways and management mechanisms for the construction of double-qualified teachers, and create an environment suitable for the growth of double-qualified teachers. Higher vocational teachers should renew their ideas, actively plan for self-improvement of theoretical knowledge and practical ability, and explore the effective use of innovative teaching models and methods in class with the latest teaching concepts. Only by this way can we cultivate talents to meet the needs of higher vocational education and promote the rapid development of college higher vocational education and the healthy development of teachers themselves.

\section{REFERENCES}

[1] Luo Mengbo, Shang Xiaomei. The Present Situation and Countermeasures of Higher Vocational Education. Education and Careers, 2005. (1): 31-33.

[2] Zhang Ying. Construction $U$ of the "Double-qualified" Teacher Competency Model in Higher Vocational Colleges. Journal of Anhui Agricultural University (Social Science Edition), 2010,19 (2) : 61-64

[3] Chen Bin. Construction of Teacher Competency Model in Higher Vocational Colleges [U]. Higher Education Development and Evaluation, 201l, 27(6) : 106 -- 110

[4] Fang Xiang-yang. Research on the Competency Model of Professional Teachers in Higher Vocational Colleges [U]. Vocational and Technical Education, 2011,32 (25) : 73-77

[5] Wu Yu-feng. Problems and Countermeasures in the Cultivation of Young Teachers' Scientific Research Quality and Ability in Higher Vocational Colleges [J]. Academic Forum, 2011. 